Gitation: Aguilar-Morales, M. A., De la Cruz Olvera, A., , ArchundiaGarduño, E., Cruz-Monterrosa, R. G., Díaz-Ramírez, M., Miranda de la Lama, G. C., Fabela-Morón, M. F., Martínez- García, C. G., GarcíaMartínez, A., \& Rayas-Amor, A. A. (2021). Lippia graveolens (Lamiales: Verbenaceae) and Oryganum vulgare (Lamiales: Lamiaceae) obtained by means of the in vitro propagation technique. Agro Productividad. https:/ doi.org/10.32854/agrop.v14il1.217

Editor in Chief: Dr. Jorge Cadena Iñiguez

Received: April 28, 2021. Accepted: October 15, 2021 Published on-line: November 26, 2021

This work is licensed under a Creative Commons Attribution-NonCommercial 4.0 International license.

\section{Lippia graveolens (Lamiales: Verbenaceae) and Oryganum vulgare (Lamiales: Lamiaceae) obtained by means of the in vitro propagation technique}

\author{
Aguilar Morales, María A. ${ }^{{ }^{*}}$; De la Gruz Olvera, Armandina ${ }^{2}$, Archundia Garduño, E. ${ }^{3}$, \\ Gruz Monterrosa, Rosy G. ${ }^{1}$; Díaz Ramírez, Mayra ${ }^{1}$; Miranda de la Lama, Genaro G. ${ }^{1}$; \\ Fabela Morón, Miriam F. ${ }^{1}$; Martínez García, Carlos G. ${ }^{4}$; García Martínez Anastacio ${ }^{5}$; \\ Rayas Amor, Adolfo A. ${ }^{1^{*}}$
}

1 Universidad Autónoma Metropolitana, Departamento de Ciencias de la Alimentación. División de Ciencias Biológicas y de la Salud. Unidad Lerma. Lerma de Villada, Estado de México. CP. 52006.

2 Secretaria de Medio Ambiente, Laboratorio de Biotecnología, Departamento de Producción de Planta. Dirección de Restauración y Fomento Forestal. Protectora de Bosques del Estado de México, Metepec, Estado de México.

3 Secretaria de Desarrollo Agropecuario, Instituto de Investigación y Capacitación Agropecuaria, Acuícola y Forestal del Estado de México. C.P. 52140. Metepec, Estado de México.

4 Universidad Autónoma del Estado de México, Instituto de Ciencias Agropecuarias y Rurales, Campus el Cerrillo. El Cerrillo Piedras Blancas, G.P. 50090, Toluca, Estado de México, México.

5 Universidad Autónoma del Estado de México, Centro Universitario UAEM Temascaltepec, México. Temascaltepec de González Estado de México. C.P. 51300

* Correspondence: ascencali@yahoo.com.mx; a.rayas@correo.ler.uam.mx;

\begin{abstract}
Objective: The objective of this study was to establish the method of propagation of Oryganum vulgare and Lippia graveolens employing a plant tissue culture technique that decreased the phenolization percentages and increased the multiplication coefficients.

Design/methodology/approach: The in vitro germination percentage was evaluated in both MS and MS medium + activated carbon. Microcuttings (small shoots) of both species were established in base medium added with different antioxidant agents to decrease the phenolization of explants; the treatments were arranged in a completely randomized block design. For the propagation phase, a completely randomized factorial design was used, where the auxin/cytokinin phytoregulators, type of explants (axillary buds and leaves), and the species (Lippia graveolens and Oryganum vulgare) were considered as factors.

Results: Maximum germination $(63.3 \% \pm 12.5)$ was obtained on day 15 in both culture media for L. graveolens and $O$. vulgare. The use of antioxidant agents mainly activated carbon, increased the in vitro establishment and activation of vegetative buds in both species by up to $90 \%$. There were significant differences in the variables evaluated regarding the treatments, the explant, and the species in the multiplication phase. The combination $1.0 / 0.5 \mathrm{mg} \mathrm{L}^{-1} \mathrm{BA} / \mathrm{AIB}$ induces callus formation for both species. When used as leaf explants, callus formation was potentiated.
\end{abstract}

Study Limitations/Implications: The results presented are advances from a long-term experiment.

Findings/conclusions: The germination of L. graveolens seeds can be achieved in MS medium after 15 days. Microcuttings of both $L$. graveolens and $O$. vulgare were successfully established in MS basal medium enriched with $1 \mathrm{~g} \mathrm{~L}^{-1}$ charcoal that showed low oxidation percentages and induced up to $90 \%$ the production of shoots

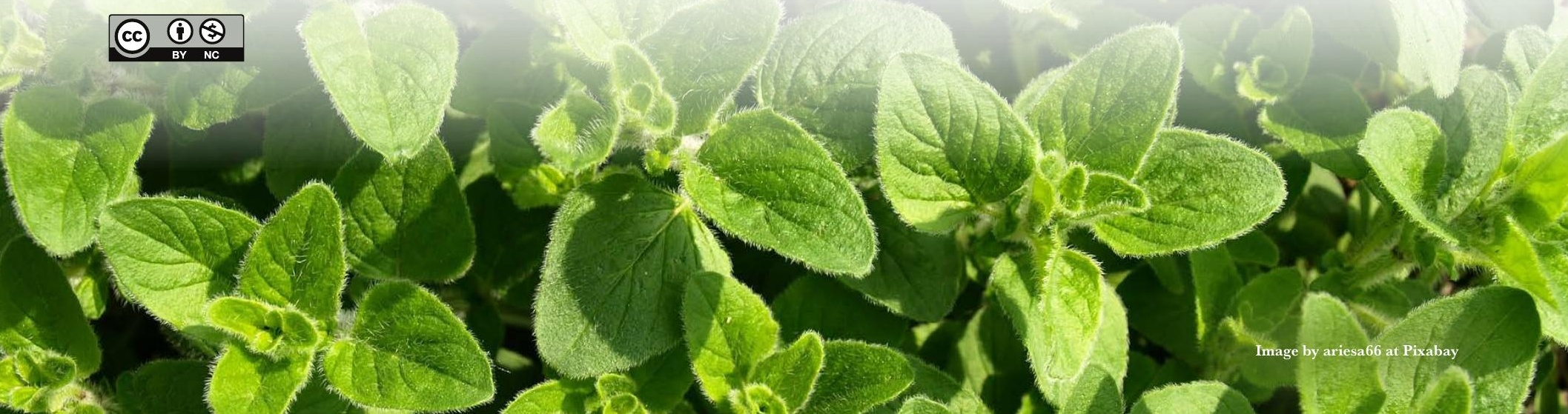


in the explants. The mixture of $1.0 / 0.5 \mathrm{mg} \mathrm{L}^{-1} \mathrm{BA} / \mathrm{AIB}$ induces callus formation for both species; when this medium is in contact with leaves as an explant, its formation is potentiated, achieving diameters up to $15 \mathrm{~mm}$. In order to achieve the induction of shoots and roots, buds should be established in MS medium enriched with $0.5 \mathrm{mg} \mathrm{L}^{-1}$ IBA for both species; this mixture encreased the multiplication coefficients.

Keywords: Micropropagation, Mexican oregano, phenolization, multiplication coefficient, plant growth regulators.

\section{INTRODUCTION}

The most common oregans in Mexico are Oryganum vulgare, better known as common oregano or Greek oregano; it is a herbaceous species of the Lamiaceae family native from Europe (Arcila-Lozano et al., 2004) and Lippia graveolens, better known as Mexican oregano (Clarenc et al., 2020). The latter is a species that is distributed in the semi-arid climates of Mexico, mainly in the states of Hidalgo, Veracruz, Durango, Yucatán, Puebla, Coahuila, Oaxaca, San Luis Potosí, Querétaro, Guerrero (CONAFOR, 2011; Castellano-Hernández et al., 2013; Cortés-Chitala et al., 2021), in the vast majority of these areas this species is a wild resource in areas with a high degree of economic and social marginalization, making it necessary to establish adequate management of this resource (Castillo et al., 2017; DíazDe León et al., 2020). Around 90\% of L. graveolens production in Coahuila is obtained from wild areas (CONAFOR, 2009), causing natural regeneration and conservation of genetic variability of the species scarcity. An alternative for the conservation of wild oregans is the cultivation of plant tissues.

In vitro propagation studies of various oregans have been carried out, mainly via direct organogenesis (García-Pérez et al., 2012) using MS medium (Murashige and Skoog, 1962) combined with the auxin cytosine complex. Sánchez-Pérez et al. (2021) reported the in vitro propagation of $L$. graveolens using axillary buds enriched with $2.5 \mathrm{mg} \mathrm{L}^{-1}$ of 6-benzyl aminopurine and evaluated different luminosity intensities to make the in vitro photosynthetic process more efficient. Well (2014) reported that the micropropagation of this species from vegetative explants (microcuttings) presents a high percentage of phenolization, which prevents cultivation. Castellano-Hernández et al. (2013) reported the generation of shoots of $L$. graveolens from axillary buds of plants germinated in vitro with cytokinins and the development of shoots with the addition of auxins. Therefore, the objective of the present work was to establish the propagation method of Oryganum vulgare and Lippia graveolens employing plant tissue culture technique or micropropagation that decreases the phenolization percentages and increases the multiplication coefficients.

\section{MATERIALS AND METHODS}

\section{Selection of plant material}

The seeds of $O$. vulgare were purchased from the company HortaFlor and mother plants from the Botanical Garden of Medicinal Plants of the Institute for Research and Training, Agriculture, Agriculture and Forestry of Mexico (ICAMEX) to validate their origin.

The seeds of $L$. graveolens were collected in the community of Higuerillas, municipality of Peñamiller, Querétaro. In addition, two specimens were selected as the mother plant. 
For both species, the seeds were kept refrigerated at $10^{\circ} \mathrm{C}$ until their establishment in vitro. The mother plants were kept under greenhouse conditions at the Lerma Autonomous Metropolitan University and the mother plant in a greenhouse of the Biotechnology Laboratory of the Protectora de Bosques del Estado de México (PROBOSQUE), where all the in vitro study was carried out.

\section{In vitro establishment}

The seeds and microcuttings were used as explants. The seeds were disinfected following the micropropagation process of Thymus piperella (Sáez et al., 1994), with some modifications. The seeds were disinfected by soaking them in constant agitation for five minutes with two drops of commercial liquid soap; subsequently rinsed until the soap was removed with distilled water, followed by $30 \% \mathrm{v} / \mathrm{v}$ commercial sodium hypochlorite solution for 20 minutes and rinsed again with distilled water (three times). Afterward, they were placed in a laminar flow hood in a 70\% ethanol solution for 30 seconds and rinsed with sterilized distilled water.

A completely randomized block design was established to evaluate the seed germination of both species, ten repetitions were used for each treatment, and each repetition contained five seeds. Two treatments of base culture medium were established: T1. 100\% MS culture medium (Murashige and Skoog, 1962), with the whole mineral salts. T2. 100\% MS culture medium plus $1 \mathrm{~g} \mathrm{~L}^{-1}$ of activated carbon. Both treatments were enriched with $30 \mathrm{~g} \mathrm{~L}^{-1}$ of sucrose, $7 \mathrm{~g} \mathrm{~L}^{-1}$ of bacteriological agar, and the $\mathrm{pH}$ was adjusted to $5.7 \pm 0.1$. The treatments were placed in Gerber-type flasks with 20 milliliters of medium each; they were sterilized in an autoclave at $120^{\circ} \mathrm{C}$ for 15 minutes. Germination percentage was evaluated at 5,10 , and 15 days.

The disinfection of vegetative explants was carried out as Chanbe (2008) for common oregano microcuttings, changing the ascorbic acid by citric acid in the same concentration. As this type of species presents a high degree of oxidation due to the release of phenols at the cutting time, a completely randomized design was established with five treatments with ten repetitions per treatment to minimize phenolization. For the treatments, MS was used as the basal medium at $100 \%$ of its concentration enriched with $30 \mathrm{~g} \mathrm{~L}^{-1}$ of sucrose, $7 \mathrm{~g}$ $\mathrm{L}^{-1}$ of bacteriological agar supplemented with: $\mathrm{O} 1$ control; $\mathrm{O} 2$ with $2.5 \%$ lemon juice; $\mathrm{O} 3$ with $1 \mathrm{mg} \mathrm{L}^{-1}$ of citric acid; O4 with $1 \mathrm{~g} \mathrm{~L}^{-1}$ of activated carbon and $\mathrm{O} 5$ with $5 \%$ lemon juice. The oxidation percentage and the shoot regeneration percentage were evaluated at 30 days.

\section{Multiplication and rooting stage}

For the multiplication stage, a factorial design with five repetitions (five explants per repetition) was used, where the effect of the cytokinin-auxin complex for the stimulation of morphogenetic responses was evaluated. Factor A was the type of explant (axillary bud and leaf), and factor B was the components of the culture medium. For the latter, 6-benzyl amino purine (BAP) was used in concentrations $0,0.5$, and $1 \mathrm{mg} \mathrm{L}^{-1}$ combined with indol butyric acid at $0,0.1$, and $0.5 \mathrm{mg} \mathrm{L}^{-1}$ in MS base medium with $30 \mathrm{~g} \mathrm{~L}^{-1}$ of sucrose, $7 \mathrm{~g}$ $\mathrm{L}^{-1}$ of bacteriological agar. After 30 days of establishment, the following variables were 
evaluated: $\%$ oxidation, $\%$ of callus formation, callus diameter, $\%$ of shoot formation, shoot length, number and length of roots, and multiplication coefficient.

\section{Statistic analysis}

The variables for each phase were evaluated employing an analysis of variance. A Tukey test was performed for the variables that presented significant differences $(\mathrm{P}<0.05)$ (Steel and Torrie, 1980). The SAS software for Windows 10 was used.

\section{RESULTS AND DISCUSSION}

\section{In vitro establishment}

Regarding the in vitro establishment of seeds, O. vulgare did not germinate in any treatment. For L. graveolens, there were no significant statistical differences for the three evaluation dates, obtaining germination percentages of $30.0 \pm 7.8$ and $26.76 \pm 8.3 \%$ in $\mathrm{T} 1$ and T2, respectively, at five days. Ten days after sowing, the trend was similar, with $56.67 \pm 10.0$ and $50.0 \pm 11.4 \%$ germinated seeds. Maximum germination occurred 15 days after sowing with $63.3 \pm 12.5 \%$ for both treatments. These results were similar to those reported by Castellano-Hernández et al. (2013) for L. graveolens; they observed in vitro germination of seeds in MS medium to use them as initial micropropagation material, material that was subcultured in MS medium plus $0.5 \mathrm{mg} \mathrm{L}^{-1}$ of BA to activate $83.3 \pm 0.4 \%$ of buds. Regarding the microcuttings established as initial explants, there were significant statistical differences $(\mathrm{P}<0.001)$ between treatments, species, and treatment $\times$ species interaction in, both $\%$ of oxidation and $\%$ of explants that formed shoots.

The lowest percentage of oxidation was observed in the O4 treatment $(20.5 \% \pm 2.92)$, $\mathrm{O} 1$ showed $42.5 \% \pm 8.68$, the $\mathrm{O} 2$ and $\mathrm{O} 3$ treatments showed $46.0 \% \pm 3.28$ and $51.0 \% \pm 3.3$; respectively, and the highest oxidation was observed in $\mathrm{O} 5$ treatment $(90.0 \% \pm 3.55)$. The L. graveolens microcuttings showed a lower percentage of oxidation $(42.80 \% \pm 4.76)$ than $O$. vulgare $(57.20 \% \pm 3.78)$.

The treatment effect on the species is shown in Figure 1; it can be observed that treatment $\mathrm{O} 4(13.0 \pm 1.6 \%)$ and $\mathrm{O} 1(10.9 \pm 0.4 \%)$ had a significant effect on L. graveolens. On the other hand, O. vulgare showed less response to $\mathrm{O} 4$ treatment $(28.00 \pm 1.7 \%)$ and $\mathrm{O} 1$, where the percentage of oxidation was $78.00 \% \pm 2.9$. Thus, indicating that microcuttings as the initial explant of Mexican oregano responded well to antioxidant agents. The addition of citric acid reduced the oxidation percentages, however, when it is used in high doses it is counterproductive.

The formation of shoots was inversely proportional to oxidation; when there was more oxidation, there was less presence of shoots. The presence of activated carbon $(\mathrm{O} 4)$ considerably increased the presence of shoots $(90.5 \% \pm 3.52)$. Lippia graveolens regenerated more shoots than 0 . vulgare $(66.24 \% \pm 6.49$ and $31.72 \% \pm 7.92$, respectively).

The results of Bueno (2014) showed the contrary because he added $2 \%$ ascorbic acid to the MS base culture medium and considerably reduced the phenolization of buds used as initial explants. 


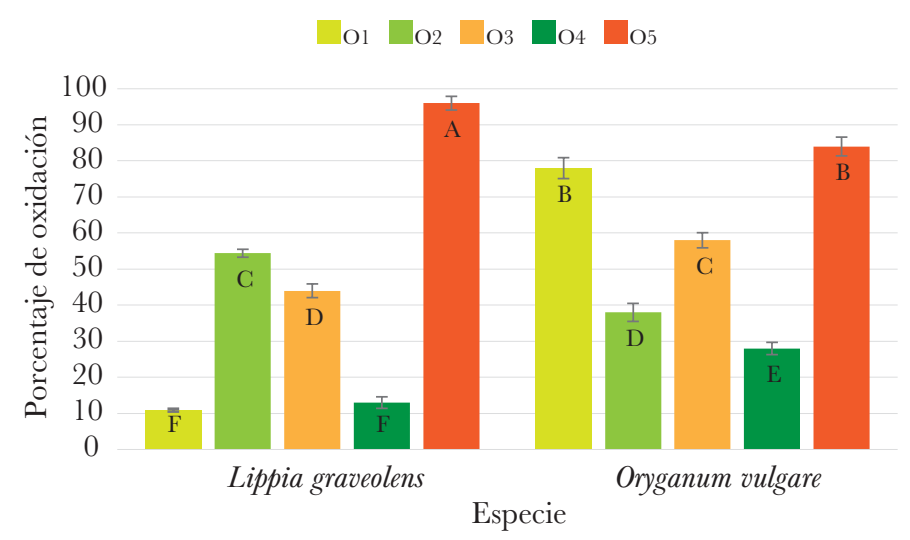

Figure 1. Effect of antioxidant agents in the culture medium for establishing microcuttings as an initial explant in Lippia graveolens and Oryganum vulgare. O1: control; O2: $2.5 \%$ lemon juice; O3: $1 \mathrm{mg} \mathrm{L}^{-1}$ of citric acid; O4: $1 \mathrm{~g} \mathrm{~L}^{-1}$ of activated carbon; O5: 5\% lemon juice. Different letters present statistically significant differences $\mathrm{P} \leq 0.05$.

\section{Multiplication and rooting stage}

For percentage of oxidation, percentage of callus formation, callus diameter, and percentage of shoot formation, there were significant statistical differences between the treatments, the species, and the explant $(\mathrm{P}<0.0001)$ except for the percentage of callus formation referring to the type of explant $(\mathrm{P}=0.7022)$ used (Table 1).

The treatments consisting of $0.5 / 0.5$ and $1.0 / 0.5 \mathrm{mg} \mathrm{L}^{-1} \mathrm{BA} / \mathrm{AIB}$ presented the lowest oxidation percentages with 12.5 and $12.4 \%$ oxidation compared to the treatment without growth regulators that presented the highest percentage of oxidation, 32.9\%. The 1.0/0.5 $\mathrm{mg} \mathrm{L}^{-1} \mathrm{BA} / \mathrm{AIB}$ treatment was isolated entirely from the other treatments, causing callus formation in $69 \%$ of the explants, and the treatment without regulators presented only $7 \%$ of the explants. In the explants, the leaf presented a high degree of oxidation compared to the bud; both explants formed callus, but the diameter of the callus was more significant in the leaf than the bud, as shown in Table 2, the more significant number of sprouts were presented with oregano buds.

The in vitro behavior of L. graveolens was better than that of $O$. vulgare, from both the leaf and the bud had the best values for callus formation, the Mexican oregano leaf formed a

Table 1. Mean squares for the in vitro multiplication stage of Lippia graveolens and Oryganum vulgare.

\begin{tabular}{l|c|c|c|c}
\hline & Oxidation & Callus formation & $\begin{array}{c}\text { Callus diameter } \\
(\mathbf{m m})\end{array}$ & Shoots formation \\
\hline Treatment(T) & $3068.3 *$ & $2852.48 *$ & $521.7 *$ & $316.79 *$ \\
\hline Species $(\mathrm{SP})$ & $194245 *$ & $12520.06 *$ & $4843.66 *$ & $1355.3 *$ \\
\hline Explant $(\mathrm{E})$ & $348668 *$ & $30.81 \mathrm{NS}$ & $919.23 *$ & $126271 *$ \\
\hline $\mathrm{T} * \mathrm{SP}$ & $3003.2 *$ & $1381.96 *$ & $251.3 *$ & $405.89 *$ \\
\hline $\mathrm{T} * \mathrm{E}$ & $3212.4 *$ & $187.70 *$ & $49.62 *$ & $121.11 *$ \\
\hline $\mathrm{SP} * \mathrm{E}$ & $3212.4 *$ & $295.23 *$ & $830.09 *$ & $0 \mathrm{NS}$ \\
\hline $\mathrm{CV}$ & 39.00 & 25.64 & 35.50 & 34.70 \\
\hline
\end{tabular}

* Significant at 0.05. NS. Not significant at 0.05 . 
Table 2. Percentages of oxidation, callus formation and diameter, and bud formation in Lippia graveolens and Oryganum vulgare.

\begin{tabular}{|c|c|c|c|c|c|}
\hline & & Oxidation (\%) & $\begin{array}{c}\text { Callus formation } \\
(\%)\end{array}$ & $\begin{array}{l}\text { Callus diameter } \\
(\mathbf{m m})\end{array}$ & $\begin{array}{c}\text { Shoots formation } \\
(\%)\end{array}$ \\
\hline \multirow{2}{*}{ Species } & Oryganum vulgare & $42.01^{\mathrm{A}}$ & $1.9^{\mathrm{B}}$ & $0.03^{\mathrm{B}}$ & $57.2^{\mathrm{B}}$ \\
\hline & Lippia graveolens & $7.88^{\mathrm{B}}$ & $88.7^{\mathrm{A}}$ & $5.4^{\mathrm{A}}$ & $66.2^{\mathrm{A}}$ \\
\hline \multirow{2}{*}{ Explant } & Leaves & $53.1^{\mathrm{A}}$ & $56^{\mathrm{A}}$ & $5.1^{\mathrm{A}}$ & $1^{\mathrm{B}}$ \\
\hline & Bud & $5.5^{\mathrm{B}}$ & $56^{\mathrm{A}}$ & $2.6^{\mathrm{B}}$ & $91.4^{\mathrm{A}}$ \\
\hline \multirow{2}{*}{ L. graveolens } & Leaves & $24.8^{\mathrm{B}}$ & $91.1^{\mathrm{A}}$ & $8.4^{\mathrm{A}}$ & $0^{\mathrm{B}}$ \\
\hline & Bud & $6.3^{\mathrm{C}}$ & $87.6^{\mathrm{A}}$ & $4.1^{\mathrm{B}}$ & $94.6^{\mathrm{A}}$ \\
\hline \multirow{2}{*}{ O. vulgare } & Leaves & $95.6^{\mathrm{A}}$ & $5.6^{\mathrm{B}}$ & $0.1^{\mathrm{C}}$ & $2.2^{\mathrm{B}}$ \\
\hline & Bud & $14.4^{\mathrm{C}}$ & $0^{\mathrm{A}}$ & $0^{\mathrm{C}}$ & $85.6^{\mathrm{A}}$ \\
\hline
\end{tabular}

Different letters represent statistically significant differences $\mathrm{P} \leq 0.05$.

large callus diameter $(8.4 \mathrm{~mm})$ (Figure 2), suggesting that the suspension cell culture of this species may be very viable to produce secondary metabolites from this explant. The leaf of O. vulgare regenerated shoots in a small proportion, thus producing direct organogenesis.

Regarding the generation of shoots by growing buds, statistical differences $(\mathrm{P}<0.05)$ were found between the treatments evaluated concerning the addition of growth regulators. For both species, the number of shoots and, therefore, the multiplication coefficient benefited when 1.0/0.0 $\mathrm{mg} \mathrm{L}^{-1} \mathrm{BA} / \mathrm{AIB}$ was used; it increased almost twice for L. graveolens and triple for $O$. vulgare (Table 3). The length of the shoots of L. graveolens increased $22.8 \mathrm{~mm}$ with $0.0 / 0.5 \mathrm{mg} \mathrm{L}^{-1} \mathrm{BA} / \mathrm{AIB}$ concerning the control, in that same concentration, up to five roots per explant with an average length of $47 \mathrm{~mm}$ compared to the control that formed 1.3 roots per explant with approximately $3.5 \mathrm{~mm}$.

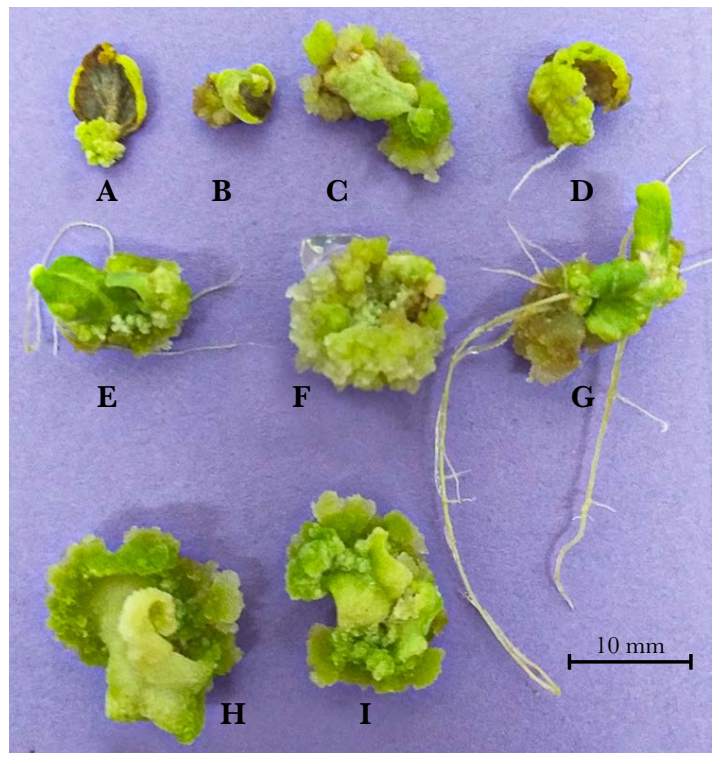

Figure 2. Lippia graveolens callus formation from leaf in MS basal medium added with 6-benzyl amino purine/ indole butyric acid in $\mathrm{mg} \mathrm{L}^{-1}$. A: Control, B: 0.5/0.0, C: 1.0/0.0, D: 0.0/0.1. E: 0.5/0.1, F: 1.0/0.1, G: 0.0/0.5, H: 0.5/0.5, I: 1.0/0.5. 
Table 3. Effect of cytosine/auxin in the multiplication and root formation stage in Lippia graveolens and Oryganum vulgare from buds.

\begin{tabular}{|c|c|c|c|c|c|}
\hline $\begin{array}{c}\text { Treatment } \\
\text { BAP/AIB mg } \mathrm{L}^{-1}\end{array}$ & $\begin{array}{l}\text { Number of } \\
\text { shoots }\end{array}$ & $\begin{array}{l}\text { Shoot length } \\
(\mathbf{m m})\end{array}$ & $\begin{array}{c}\text { Root number/ } \\
\text { explant }\end{array}$ & $\begin{array}{l}\text { Root length } \\
(\mathrm{mm})\end{array}$ & $\begin{array}{c}\text { Propagation } \\
\text { coefficient }\end{array}$ \\
\hline \multicolumn{6}{|l|}{ Oryganum vulgare } \\
\hline $0.0 / 0.0$ & $1.5^{\mathrm{BC}}$ & $16.6^{\mathrm{AB}}$ & $0.0^{\mathrm{A}}$ & $0.0^{\mathrm{A}}$ & $4.4^{\mathrm{BC}}$ \\
\hline $0.5 / 0.0$ & $1.9^{\mathrm{ABC}}$ & $12.8^{\mathrm{B}}$ & $0.0^{\mathrm{A}}$ & $0.0^{\mathrm{A}}$ & $5.1^{\mathrm{ABC}}$ \\
\hline $1.0 / 0.0$ & $2.5^{\mathrm{A}}$ & $18.2^{\mathrm{AB}}$ & $0.0^{\mathrm{A}}$ & $0.0^{\mathrm{A}}$ & $7.3^{\mathrm{A}}$ \\
\hline $0.0 / 0.1$ & $1.6^{\mathrm{BC}}$ & $17.4^{\mathrm{AB}}$ & $0.0^{\mathrm{A}}$ & $0.0^{\mathrm{A}}$ & $4.9^{\mathrm{ABC}}$ \\
\hline $0.5 / 0.1$ & $1.6^{\mathrm{BC}}$ & $12.5^{\mathrm{B}}$ & $0.0^{\mathrm{A}}$ & $0.0^{\mathrm{A}}$ & $3.9^{\mathrm{BC}}$ \\
\hline $1.0 / 0.1$ & $1.8^{\mathrm{ABC}}$ & $16.2^{\mathrm{AB}}$ & $0.0^{\mathrm{A}}$ & $0.0^{\mathrm{A}}$ & $4.8^{\mathrm{ABC}}$ \\
\hline$\underline{0.0 / 0.5}$ & $1.1^{\mathrm{C}}$ & $\underline{22.9}^{\mathrm{A}}$ & $0.1^{\mathrm{A}}$ & $1.0^{\mathrm{A}}$ & $3.4^{\mathrm{C}}$ \\
\hline $0.5 / 0.5$ & $1.4^{\mathrm{BC}}$ & $18.3^{\mathrm{AB}}$ & $0.0^{\mathrm{A}}$ & $0.0^{\mathrm{A}}$ & $3.8^{\mathrm{C}}$ \\
\hline $1.0 / 0.5$ & $2.0^{\mathrm{ABC}}$ & $16.3^{\mathrm{AB}}$ & $0.0^{\mathrm{A}}$ & $0.0^{\mathrm{A}}$ & $6.5^{\mathrm{AB}}$ \\
\hline \multicolumn{6}{|l|}{ Lippia graveolens } \\
\hline $0.0 / 0.0$ & $1.8^{\mathrm{DE}}$ & $22.1^{\mathrm{BC}}$ & $1.3^{\mathrm{C}}$ & $3.5^{\mathrm{C}}$ & $4.0^{\mathrm{D}}$ \\
\hline $0.5 / 0.0$ & $3.0^{\mathrm{CD}}$ & $16.9^{\mathrm{CD}}$ & $0.2^{\mathrm{D}}$ & $0.1^{\mathrm{C}}$ & $8.7^{\mathrm{BC}}$ \\
\hline $1.0 / 0.0$ & $4.4^{\mathrm{A}}$ & $14.4^{\mathrm{CD}}$ & $0.0^{\mathrm{D}}$ & $0.0^{\mathrm{C}}$ & $13.1^{\mathrm{A}}$ \\
\hline $0.0 / 0.1$ & $1.7^{\mathrm{DE}}$ & $29.4^{\mathrm{B}}$ & $2.3^{\mathrm{B}}$ & $14.1^{\mathrm{B}}$ & $5.1^{\mathrm{D}}$ \\
\hline $0.5 / 0.1$ & $3.2^{\mathrm{BC}}$ & $19.2^{\mathrm{C}}$ & $0.0^{\mathrm{D}}$ & $0.0^{\mathrm{C}}$ & $10.1^{\mathrm{BC}}$ \\
\hline $1.0 / 0.1$ & $3.6^{\mathrm{AB}}$ & $9.0^{\mathrm{D}}$ & $0.0^{\mathrm{D}}$ & $0.0^{\mathrm{C}}$ & $4.3^{\mathrm{D}}$ \\
\hline$\underline{0.0 / 0.5}$ & $1.3^{\mathrm{E}}$ & $44.9^{\mathrm{A}}$ & $\underline{5.1}^{\mathrm{A}}$ & $47.0^{\mathrm{A}}$ & $5.9^{\mathrm{DC}}$ \\
\hline $0.5 / 0.5$ & $2.3^{\mathrm{CD}}$ & $23.0^{\mathrm{BC}}$ & $0.0^{\mathrm{D}}$ & $0.0^{\mathrm{C}}$ & $6.0^{\mathrm{DC}}$ \\
\hline $1.0 / 0.5$ & $2.0^{\mathrm{DE}}$ & $9.5^{\mathrm{D}}$ & $0.0^{\mathrm{D}}$ & $0.0^{\mathrm{C}}$ & $4.0^{\mathrm{D}}$ \\
\hline
\end{tabular}

Different letters present statistically significant differences $\mathrm{P} \leq 0.05$.

The results of this research agree with those reported by García-Pérez et al. (2012); via direct organogenesis, they obtained shoots of 0 . vulgare in MS medium enriched with 1 $\mathrm{mg} \mathrm{L}^{-1}$ of BA. Castellano-Hernández et al. (2013) reported the induction of shoots of $L$. graveolens in MS medium enriched with $2.0 \mathrm{mg} \mathrm{L}^{-1}$ of BA, achieving $2.4 \pm 3.8$ shoots per explant, due to a combination of $0.1 / 0.5 \mathrm{mg} \mathrm{L}^{-1}$ of IAA/BA of $6 \mathrm{~mm}$ and the induction of roots with 0.1 and $0.5 \mathrm{mg} \mathrm{L}^{-1}$ of IAA with $7.3 \pm 4$ and $5.3 \pm 2.9$ roots per explant. The increase in the shoot length $(63 \pm 17 \mathrm{~mm})$ and roots $(100.0 \pm 47 \mathrm{~mm})$ and up to 15 roots per explant were reported by adding $1.5 \mathrm{mg} \mathrm{L}^{-1}$ of IBA.

The results of this work surpassed those reported for L. graveolens and L. alba (Bueno, 2014), where DM added with $2 \mathrm{mg} \mathrm{L}^{-1}$ of BA reported three shoots per explant at 28 days in $L$. alba and DM added with $0.5 / 0.1 / 3 \mathrm{mg} \mathrm{L}^{-1}$ of BA/AIB/phloridzin, they obtained 2.2 shoots per explant at 22 days. Sanchez-Velázquez et al. (2021) reported the micropropagation of L. graveolens from axillary buds in MS medium enriched with $2.5 \mathrm{mg}$ $\mathrm{L}^{-1}$ of BA, obtaining shoots with great success.

\section{GONGLUSION}

The germination of $L$. graveolens seeds can be achieved in MS medium after 15 days. Microcuttings of both L. graveolens and O. vulgare were successfully established in MS basal 
medium enriched with $1 \mathrm{~g} \mathrm{~L}^{-1}$ charcoal that showed low oxidation percentages and induced up to $90 \%$ the production of shoots in the explants. The mixture of $1.0 / 0.5 \mathrm{mg} \mathrm{L}^{-1} \mathrm{BA} / \mathrm{AIB}$ induces callus formation for both species; when this medium is in contact with leaves as an explant, its formation is potentiated, achieving diameters up to $15 \mathrm{~mm}$. In order to achieve the induction of shoots and roots, buds should be established in MS medium enriched with $0.5 \mathrm{mg} \mathrm{L}^{-1}$ IBA for both species; this mixture encreased the multiplication coefficients.

\section{AGKNOWLEDGMENTS}

This work was supported by the program "APOYOS POSDOCTORALES EN CUERPOS ACADEMICOS CONSOLIDADOS Y EN CONSOLIDACION (PRODEP)", grant number 511-62019-4692 (Dra. María Ascencion Aguilar Morales, Departamento de Ciencias de la Alimentación de la Universidad Autónoma Metropolitana Unidad Lerma” and Protectora de Bosques del Estado de México (PROBOSQUE). Authors are grateful with the producers from the community of Higuerillas municipality of Peñamiller, Querétaro for the donation of seeds and plants of Lippia graveolens and with the Instituto de Investigación y Capacitación, Agropecuaria, Agrícola y Forestal del Estado de México (ICAMEX) for the donation of Oryganum vulgare plants; their support is fully appreciated.

\section{REFERENGES}

Acevedo, Diofanor, Navarro, Mario, \& Monroy, Luis. (2013). Composición Química del Aceite Escencial de Hojas de Orégano (Origanum vulgare). Información tecnológica, 24(4), 43-48. https://dx.doi.org/10.4067/ S0718-07642013000400005.

Arcila-Lozano, Cynthia Cristina, Loarca-Piña, Guadalupe, Lecona-Uribe, Salvador, \& González de Mejía, Elvira. (2004). El orégano: propiedades, composición y actividad biológica de sus componentes. Archivos Latinoamericanos de Nutrición, 54(1), 100-111. Recuperado en 23 de febrero de 2021, de http://ve.scielo. org/scielo.php?script=sci_arttext\&pid=S0004-06222004000100015\&lng=es\&tlng=es.

Barrales Cureño, H. J., \& Ramírez Sepúlveda, M. F. (2013). Una revisión sobre la producción de taxoides anticancerígenos en cultivos in vitro de callos y células de Taxus spp. Revista Colombiana de Biotecnología, 15(2), 167-177. https://doi.org/10.15446/rev.colomb.biote.v15n2.41743.

Bueno, D.A.Y. (2014). Estimulación abiótica de la acumulación de compuestos bioactivos en dos especies de Lippia. Tesis doctoral en Ciencias y Tecnología en la Opción Terminal de Biotecnología Productiva. Centro de Investigación y Asistencia en Tecnología y Diseño del Estado De Jalisco, A.C. http://ciatej. repositorioinstitucional.mx/jspui/handle/1023/487.

Castellanos-Hernández, O. A., Acevedo-Hernández, G. J., Torres-Morán, M. I., Zurita, F., GutiérrezLomelí, M., Del Toro-Sánchez, C. L., \& Rodríguez-Sahagún, A. (2013). In vitro clonal propagation and regeneration of the commercially important plant Mexican oregano (Lippia graveolens). In Vitro Cellular and Developmental Biology - Plant. https://doi.org/10.1007/s1 1627-013-9538-4.

Castillo, I.O., Almazán, A.J.S., Arellano, J.D.J.E., Vázquez, C. (2017). Recolección y Comercialización del Orégano (Lippia spp) en el Semi-Desierto Mexicano, Un Caso De Estudio: Reserva Ecológica Municipal Sierra y Cañón De Jimulco, México. Revista Mexicana de Agronegocios. 41:684-695.

Chambe, G. E. (2008). Introducción al sistema de cultivo in vitro y micro propagación de cinco ecotipos de orégano (Origanum vulgare L.) en condiciones de laboratorio. Tesis de grado.Facultad de Ciencias Agrícolas de la Universidad Nacional Jorge Basadre Grohmann de Tacna. http://repositorio.unjbg. edu.pe/handle/UNJBG/608

Clarenc Aarland, Rayn, Castellanos-Hernández, Osvaldo Adrián, Rodríguez-Sahagún, Araceli, \& AcevedoHernández, Gustavo Javier. (2020). Efecto del estrés salino sobre la morfología y fitoquímica de orégano mexicano (Lippia graveolens Kunth) cultivado in vitro. Biotecnia, 22(3), 131-137. Epub 10 de febrero de 2021.https://doi.org/10.18633/biotecnia.v22i3.1223

Comisión Nacional Forestal CONAFOR. (2009). Fichas de información comercial de productos forestales. Coordinación General de Educación y Desarrollo Tecnológico, Gerencia de Desarrollo y Transferencia de Tecnología. Fondo Sectorial para la Investigación, el Desarrollo y la Innovación Tecnológica Forestal, SEMARNAT, México, D. F. 
Comisión Nacional Forestal CONAFOR. (2011). Paquete tecnológico para la producción de orégano (Lippia spp.). Coordinación General de Educación y Desarrollo Tecnológico. Gerencia de Desarrollo y Transferencia de Tecnología. Zapopan, Jalisco, México. https://www.conafor.gob.mx/biblioteca/ OREGANO.pdf

Cortés-Chitala, M. del C., Flores-Martínez, H., Orozco-Ávila, I., León-Campos, G., Suárez-Jacobo, Á., Estarrón-Espinosa, M., \& López-Muraira, I. (2021). Identification and Quantification of Phenolic Compounds from Mexican Oregano (Lippia graveolens HBK) Hydroethanolic Extracts and Evaluation of Its Antioxidant Capacity. Molecules, 26(3), 702. doi:10.3390/molecules26030702.

Díaz-De León, G.I., González-Álvarez, M., Guzmán-Lucio, M.A., Núñez-Guzmán, G.R., \& MorenoLimón, S. (2020). El orégano de los géneros Lippia (Verbenaceae) y Poliomintha (Lamiaceae) en el Estado de Nuevo León, México. Polibotánica, (50), 1-18. Epub 25 de noviembre de 2020. https://doi. org/ $10.18387 /$ polibotanica.50.1.

García-Pérez, Enrique, Fernando Francisco, Castro-Álvarez, Gutiérrez-Uribe, Janet Alejandra, \& García-Lara, Silverio. (2012). Revisión de la producción, composición fitoquímica y propiedades nutracéuticas del orégano mexicano. Revista mexicana de ciencias agrícolas, 3(2), 339-353. Recuperado en 22 de febrero de 2021, de http://www.scielo.org.mx/scielo.php?script=sci_arttext\&pid=S2007-09342012000200010\&ln $\mathrm{g}=\mathrm{es} \&$ tlng $=\mathrm{es}$.

Murashige, T. y Skoog, F. (1992). A revised medium for rapid growth and bioassays with tobacco tissue culture. Physiologia Plantarum, Copenhagan 15:473-497.

Pérez-Alonso, N., y Jiménez, E. (2011). Producción de metabolitos secundarios de plantas mediante el cultivo in vitro. Biotecnología Vegetal, 11 (4).

Sáez, F., Sánchez, P. \& Piqueras, A. (1994). Micropropagation of Thymus piperella. Plant Cell Tiss Organ Cult. 39: 269-272. https://doi.org/10.1007/BF00035981

Sánchez-Velázquez E. Rodríguez-Sahagún Araceli, Acevedo-Hernández Gustavo J., Aarland Rayn C. y Castellanos-Hernández Osvaldo A. (2021). Effect of light sources on the micropropagation of mexican origanum (Lippia graveolens). e-CUCBA. 15(8): 44-52. 